\title{
Performance pay remuneration for consultants in the NHS: is the current system fair and fit for purpose?
}

\author{
Pete Abel ${ }^{1} \quad$ Aneez Esmail ${ }^{2}$
}

J R Soc Med 2006;99:487-493

Despite reforms to the performance pay review system for NHS consultants, little has changed since the original Distinction Awards Scheme was conceived in 1948. Inherent weaknesses and biases in the scheme persist and result in discrimination against women and ethnic minority consultants in the allocation of awards. The literature on performance-related pay suggests that such schemes can be inappropriate in a public sector health service. The continued focus on rewarding individuals in performancerelated pay schemes can seem out of place in the modern era where there is an increasing focus on the performance of teams.

\section{INTRODUCTION}

How to reward doctors for performance over and above their basic responsibilities has always been contentious. George Bernard Shaw ${ }^{1}$ recognized that the profit motive and doctors' entrepreneurialism create the wrong incentives for good medical practice and it is taken for granted that the professional ethic requires doctors to place the needs of the patient above all else. Any suggestion that extra financial rewards be given for the clinical care they deliver raises possible conflicts of interest because it becomes more difficult to determine if doctors are sacrificing patients' needs to financial expediency. Yet most doctors who practise in the developed world are part of organizational systems in which pay is linked to 'merit' and to some form of performance appraisal. Of course, in the medical field, pay is rarely linked directly to clinical performance but it is frequently contingent on clinically related fields-for example, rational prescribing, meeting waiting list targets and taking management decisions which may impact directly on patient care. In UK general practice it is not unusual for doctors who meet their prescribing budgets to be financially rewarded by keeping the savings. During the early 1990s, when GP fund-holding was being promoted, many benefited directly from savings made to clinical budgets. In the hospital sector the existence of discretionary

\footnotetext{
${ }^{1}$ Research Assistant and ${ }^{2}$ Professor of General Practice, Division of Primary Care, School of Medicine, Faculty of Medical and Human Sciences, University of Manchester, UK

Correspondence to: Professor Aneez Esmail

E-mail: aneez.esmail@manchester.ac.uk
}

awards and distinction awards can be considered as a form of performance-related pay (PRP) and it is in this context that this paper discusses the issue of pay for performance.

This paper examines the development of the NHS merit pay scheme, reviews the operation of the merit pay schemes with particular reference to the issues of discrimination, and discusses the PRP scheme and whether such schemes are appropriate for rewarding individuals in health-care systems where teamwork is becoming increasingly important.

\section{PRP SCHEMES AND THE PROBLEMS OF DISCRIMINATION AND BIAS}

The Distinction Award Scheme - or 'merit award' scheme, as it was commonly known — was introduced in 1948 at the formation of the NHS. The scheme was devised by Aneurin Bevan and Lord Moran to persuade the most senior and influential members of the profession to accept the introduction of the NHS. At the time, Bevan was reported to have commented that 'ultimately, I had to stuff their mouths with gold'. ${ }^{2}$ Such a pragmatic approach may have helped achieve the acceptance of the modern NHS by the medical profession, and for Bevan the ends certainly justified the means. However, throughout nearly 60 years of operation the scheme has attracted severe criticism, from both within and without the medical profession, for the perceived secrecy, unfairness and discrimination in the awards allocation process. Even the Government's own review of the scheme in 2001 identified that the 'main concern expressed was about equality and monitoring. A large number of consultants feel discriminated against on the basis of race, gender, speciality and degree of management contribution.' ${ }^{3}$

In the NHS Plan, published in 2000, the government set out changes to the Distinction Awards and Discretionary Points Schemes. These schemes would be merged and the majority of new awards would go to those who made the biggest contribution to delivery and improving local health services. In 2002, the DoH announced that the new scheme would be known as 'Clinical Excellence' Awards (CEA), and the scheme came into operation during 2003/2004.

Since its introduction, the merit award scheme has always been identified by both the BMA and the Department of Health as a PRP scheme and negotiations between the two organizations on the scheme have 
consistently centred on how high-performing doctors could be rewarded for their contribution to the NHS. ${ }^{4-6}$

Whilst merit awards can be considered as a form of individual PRP, however, it should be noted that the awards are not available to all nominated and eligible consultants. The DoH's own targets set out their intention to increase the number of consultants receiving awards from under one half to around two-thirds of consultants. ${ }^{7}$ The policy guidance sets out the mechanism through which these cash limits are applied. ${ }^{8}$

It is clear that the old distinction awards and new CEA scheme were considered to be a form of PRP and also that the CEA scheme looks set to continue to form one of the main mechanisms by which consultants receive "pay for performance' rewards.

Proponents of PRP schemes have argued that such schemes have a range of rationales. Cutler and Waine described PRP schemes within the concept of 'New Public Management', and explained how such schemes were consistent with incentive structures and allowed a "more direct relationship between material rewards and "performance".'9 Dowling and Richardson suggested that PRP schemes may be introduced for a variety of reasons, including 'attempting to overcome problems with existing incremental systems, to improve employee motivation at work, to promote cultural and organizational change, to improve communication with the work-force, to reduce problems of recruitment and retention, to individualize employee relations, improve the fairness of the payment system, to reduce trade union influence, to increase the responsibility and influence of line managers, to generate employee commitment or to tighten financial control.' ${ }^{10}$ Harrington argued that the concept of performance appraisals and relating an individual's performance to their salaries was a 'sound principle that is required for any organization to excel' and that where problems occurred with PRP schemes these were caused by the 'ineffective way many organizations implemented the concept.' 11 The ineffective implementation of such schemes has led to many studies which have illustrated how such PRP or 'merit' schemes are divisive and counter-productive and have introduced bias and discrimination. In 1992, Griffin, in a review of PRP schemes, reported how the 'incidence of sex bias and discrimination in performance systems is only beginning to be addressed. What evidence there is, though, suggests that merit pay systems may result in discrimination.' 12 In 1994, Alimo-Metcalfe concluded that PRP tended to divide the workforce, create disaffected staff, encourage adversarial relations and kill the desire to take risks, experiment and collaborate. ${ }^{13}$ Considering the widespread use of PRP schemes, the evidence that such schemes are effective is surprisingly sparse.

Since its introduction in 1948, the operation of the unchanged. Certainly up until the early 1990s the Award scheme operated in an almost totally closed and secretive manner, attributes which were severely criticized in research papers by Bruggen and Bourne between 1979 and 1987.14-18 Their analysis of the bias in the allocation of distinction awards led them to call for the system to be abolished because 'it remains immutably unfair, divisive, and in its secrecy, contemptible. No other profession would copy this system and consultants would gain respect by scrapping it - especially self-respect.' ${ }^{19}$ Interestingly, the Treasury's own evidence to the Royal Commission on doctors' remuneration in the 1960 s argued that distinction awards should be abolished as a blot on the landscape of public finance. ${ }^{20}$

Several studies have argued that the introduction of an awards scheme which was designed to appeal to the elite of the profession introduced systematic unfairness and bias into the awards allocation process, both between NHS specialties and on the basis of gender. ${ }^{21-24}$

Responding to the criticisms and recommendations in the 1994 Kendall Report, the Advisory Committee on Distinction Awards (ACDA) began publishing annual reports. The first report was published in 1994 but it was not until 1996 that details of individual consultants-including a breakdown by specialty, ethnicity and gender-was published. ${ }^{25}$

Following research by Esmail and colleagues which highlighted the disparities in distinction awards being awarded to white and non-white consultants, ${ }^{26}$ the 1998 ACDA annual report stated that discussions had been held with the Commission for Racial Equality and that 'the Commission felt that one of the explanations for the relatively low proportion of awards held by consultants from ethnic minority groups might be some "indirectly discriminatory effects arising from the application of the current criteria,',27

During 1998 the government announced that the NHS was to be included within the Race Relations $\mathrm{Act}^{28}$ and, in a 2001 consultation paper on a proposed new consultant reward scheme, re-stated its concerns regarding inequalities within the allocation of distinction awards and acknowledged that women consultants and consultants from ethnic minorities had 'received a disproportionately small number of awards'. ${ }^{29}$

The 2001 consultation document on the Clinical Excellence Awards stated that 'for too long the two awards schemes have lent themselves to perceptions of bias and unfairness. It is not always clear why some consultants have received awards, and others not.' 30

In addition, individual consultants began taking their NHS employers to industrial tribunals to challenge the way that distinction awards or discretionary points had been awarded or withheld. In many cases the NHS Trusts 


\begin{tabular}{|c|c|c|c|c|}
\hline \multirow[b]{2}{*}{ Year } & \multicolumn{2}{|c|}{$\begin{array}{l}\text { Likelihood of obtaining and award } \\
\text { (95\% confidence intervals) }\end{array}$} & \multicolumn{2}{|c|}{$\begin{array}{l}\text { Percentage differences between } \\
\text { white and non-white consultants }\end{array}$} \\
\hline & $\begin{array}{l}\text { Male : Female } \\
\text { differences }\end{array}$ & $\begin{array}{l}\text { White : Non-white } \\
\text { differences }\end{array}$ & White & Non-White \\
\hline 1995 & $2.31(2.13-2.51)$ & $3.70(3.03-4.52)$ & 13.68 & 4.45 \\
\hline 1996 & $2.82(2.47-3.22)$ & $3.54(2.91-4.30)$ & 14.02 & 4.4 \\
\hline 1997 & $2.74(2.42-3.11)$ & Not available & - & - \\
\hline 1998 & $2.45(2.18-2.75)$ & $3.40(2.87-4.03)$ & 15.66 & 5.17 \\
\hline 1999 & $2.48(2.2-2.80)$ & 3.39 (2.88-3.99) & 15.19 & 5.01 \\
\hline 2000 & $2.35(2.39-2.63)$ & $3.06(2.64-3.50)$ & 14.94 & 5.43 \\
\hline 2001 & $2.28(2.04-2.54)$ & $3.16(2.73-3.66)$ & 14.56 & 5.11 \\
\hline
\end{tabular}

${ }^{\star}$ For a description of the methods see Esmail et al. ${ }^{26}$

reached out-of-court settlements, which included nonreporting clauses and also prevented precedents from being established. In several cases, however, Trusts had to concede that awards procedures had been flawed. ${ }^{31,32}$ In a landmark ruling one tribunal chair stated ' Such a high level of subjectivity [in the awards of discretionary points] is anathema to the successful application of equal opportunity guidelines since it works to the disadvantage of ethnic minorities, both in operation and perception ... [The case fell] into the worst category of racial discrimination against a senior medical professional. ${ }^{33}$

However, despite the Government pledges and changes to the allocation criteria, research in 2002 for the Medical Practitioners Union (MPU) showed that for women and non-white consultants the allocation of distinction awards had hardly changed since 1998. Table 1 illustrates how little the odds ratio or likelihood of a woman consultant receiving a Distinction Award in comparison to a male colleague had improved. Equally, there had been little improvement for non-white consultants.

Similar problems were found with the Discretionary Points awards schemes which have been merged into the Clinical Excellence Award scheme. Using previously unpublished data, Esmail and colleagues ${ }^{34}$ showed that $56 \%$ of white consultants had been awarded discretionary points whilst only $41 \%$ of non-white consultants had such awards. For female consultants compared to male consultants the figures were $44 \%$ and $55 \%$. The higher the level of award, the greater was the disadvantage. At the highest level of award, white consultants were over three times more likely to receive awards compared to their nonwhite colleagues. The analysis of the data also showed that the likelihood of receiving a discretionary point award varied widely across the medical specialties.
In some specialties, white consultants were nearly five times more likely to receive awards compared with nonwhite consultants (Trauma \& Orthopaedics 4.59, General Surgery 4.36) (Table 2).

Following the publication of these results the ACDA initiated research which examined the allocation of Distinction Awards in greater detail. They had access to more detailed data and so could make allowance for possible confounding variables, such as consultant length of service. The study found that ' . . . under-representation of women and ethnic minority doctors diminished substantially after adjustment for confounding variables, but [that] some under-representation remained . . . and that ' . . . underrepresentation of ethnic minority doctors mainly occurred among those who had received their basic medical training abroad'. ${ }^{35}$ Overall the study found that 'for consultants who qualified in the United Kingdom, those from ethnic minorities were under-represented in the past' but that 'for awards made in recent years, no significant differences exist between white and non-white doctors once allowance has been made for year of appointment'.

This would be reassuring if it wasn't for the figures released in spring 2005 by the newly renamed Advisory Committee on Clinical Excellence Awards (ACCEA) which provided summary data for the Bronze Clinical Excellence awards. During the 2004 round, Bronze awards were granted to 259 white consultants (of 19,020 eligible) and 20 to non-white consultants (of 3,049 eligible). Simple analysis of the differences in proportion between white and nonwhite consultants receiving awards shows that, overall, a non-white consultant was still two times less likely to have been awarded a Bronze CEA compared with a white colleague.

Preliminary analysis of data collected for a 'Survey of Consultant Members in England on the Clinical Excellence 
Table 2 Allocation of DPAs to white and non-white consultants by selected specialty (England at 30 September 2001)*

\begin{tabular}{llll}
\hline Specialty & $\begin{array}{l}\text { White } \\
\text { consultants } \\
\text { with a DPA (\%) }\end{array}$ & $\begin{array}{l}\text { Non-white } \\
\text { consultants } \\
\text { with a DPA (\%) }\end{array}$ & $\begin{array}{l}\text { Ratio of white to } \\
\text { non-white consultants } \\
\text { receiving a DPA (95\% Cl) }\end{array}$ \\
\hline Plastic surgery & 49 & 10 & $5.25(1.76-15.64)$ \\
Trauma \& orthopaedic surgery & 43 & 9 & $4.59(3.11-6.76)$ \\
General Surgery & 70 & 16 & $4.36(3.26-5.83)$ \\
Clinical neurophysiology & 49 & 11 & $4.38(1.14-16.84)$ \\
Neurosurgery & 60 & 14 & $4.17(1.14-15.21)$ \\
Obstetrics \& Gynaecology & 62 & 16 & $3.95(2.94-5.32)$ \\
Dermatology & 54 & 15 & $3.68(1.92-7.04)$ \\
Histopathology & 55 & 17 & $3.25(2.31-4.56)$ \\
Anaesthetics & 41 & 13 & $3.23(2.6-4.0)$ \\
Cardio-thoracic Surgery & 50 & 17 & $3.03(1.5-6.09)$ \\
Neurology & 46 & 15 & $2.91(1.45-5.84)$ \\
Ophthalmology & 43 & 16 & $2.7(1.85-3.96)$ \\
Urology & 64 & 24 & $2.66(1.84-3.84)$ \\
Rheumatology & 53 & 22 & $2.43(1.48-3.97)$ \\
Chemical Pathology & 60 & 26 & $2.32(1.15-4.69)$ \\
Haematology & 65 & 29 & $2.26(1.56-3.28)$ \\
General psychiatry & 57 & 28 & $2.05(1.73-2.45)$ \\
Clinical radiology & 54 & 25 & $2.15(1.75-2.65)$ \\
Accident \& Emergency medicine & 45 & 40 & $2.17(1.49-3.17)$ \\
Geriatric medicine & 54 & $1.84(1.48-2.30)$ \\
Child \& adolescent psychiatry & 54 & $1.15(0.85-1.55)$ \\
Med microbiology \& virology & 55 & & \\
\hline
\end{tabular}

${ }^{*}$ For a description of the methods see Esmail et al. ${ }^{34}$ DPA, Discretionary Point Award

\section{Box 1 Why do 'merit' or reward schemes fail?}

In 1993, Kohn argued that PRP schemes can undermine quality management. 'Excellence pulls in one direction; rewards pull in another. Tell people that their income will depend on their productivity or performance rating, and they will focus on the numbers. Sometimes they will manipulate the schedule for completing tasks or even engage in patently unethical and illegal behaviour. ${ }^{36}$

Kohn provided a six-point framework of factors that highlight the problems with incentive or PRP programmes. These factors described how:

- Pay is not a motivator. 'Several studies over the last few decades have found that when people are asked to guess what matters to their coworkers_or, in the case of managers, their subordinates—-they assume money heads the list. But put the question directly— "What do you care about?" and pay typically ranks only fifth or sixth.'

- Rewards punish. 'Rewards have a punitive effect because they are manipulative. "Do this and you'll get that" is not much different from "Do this or here's what will happen to you".'

- Rewards rupture relationships. 'Relationships among employees are often casualties of the scramble for rewards, and reduce the possibilities of co-operation.'

- Rewards ignore reasons. 'In order to solve problems in the work place, managers must understand what caused them ... Relying on incentives to boost productivity does nothing to address possible underlying problems and bring about meaningful change . . . Pay for performance may actually impede the ability of managers to manage.'

- Rewards discourage risk-taking. " "People will do precisely what they are asked to do if the reward is significant", enthuses a proponent of pay-for-performance programs. [But] here is the root of the problem. Whenever people are encouraged to think about what they will get for engaging in a task, they become less inclined to take risks or explore possibilities ... In a word, the number one casualty of rewards is creativity.'

- Rewards undermine interest. 'If our goal is excellence, no artificial incentive can ever match the power of intrinsic motivation. People who do exceptional work may be glad to be paid and even more glad to be well paid, but they do not work to collect a paycheck. They work because they love what they do.' 
Awards Scheme' undertaken by the BMA's Health Policy and Economic Research Unit in April 2005 found that a majority of respondents thought that the awards scheme favoured 'high profile' consultants, academics and consultants involved in management and that the awards scheme acted against hard-working consultants and parttime consultants. The analysis also found that $30.4 \%$ of respondents thought that the awards scheme 'acted against' non-white consultants, with $4.2 \%$ thinking it acted in favour and $51 \%$ thinking the scheme was neutral.

This survey highlighted a similar finding made by Smith and Simpson in their review of performance pay carried out in 1994 when they stated that 'what doctors do want is both a form of contract and any mechanism for rewarding high performance that will be uniform throughout the entire NHS and between specialties.' 4

What our review of the analysis of the potential biases in the distinction award and discretionary points suggests is that the allocation of the rewards has clearly not been uniform across the NHS nor, in particular, between specialities. If bias and discrimination continues, or is perceived to exist, it matters very little what such awards schemes are called. Unless consultants can be guaranteed that they will not miss out on awards simply because they are female or come from ethnic minorities, then such systems should be replaced with more equitable mechanisms.

Part of the problem may be that although described as a PRP scheme, the cash limits imposed mean that some consultants, although deserving of an award, will be denied one because there is no more money. The negative effects of such cash limits on PRP schemes have been well documented. In 1992, the Wyatt study, undertaken by the IDS Top Pay Review, stated that one of the main reasons suggested for the failure of performance pay was that 'not enough money was available for merit awards'. ${ }^{12}$ And in 1997, Dowling and Richardson reported that many of the NHS managers they interviewed felt that any PRP increment 'depended less on personal achievement . . . than on the Trust's financial position.'

\section{DOES PRP WORK IN PUBLIC SECTOR HEALTH ORGANIZATIONS?}

The notion that the provision of a reward will lead to increased performance appears to be an article of faith amongst managers and politicians alike. In a wide-ranging and comprehensive review of PRP schemes, Kohn noted, ' $[I]$ is difficult to overstate the extent to which most managers and the people who advise them believe in the redemptive powers of rewards ${ }^{36}$ (Box 1).

Kohn also described how the acceptance of PRP was so ingrained in management practice that it was very difficult even to begin to challenge the concept, let alone describe alternatives.

Surprisingly, there appears to be little hard evidence to support claims for the effectiveness of PRP schemes, and indeed much evidence that shows that such 'merit' schemes actually undermine the processes that they are intended to enhance. Kohn describes how 'at least two dozen studies over the last three decades have conclusively shown that people who expect to receive a reward for completing a task successfully simply do not perform as well as those who expect no reward at all. ${ }^{36}$

An article in the Economist in 1992 reported that the belief in merit pay's 'efficacy is based more on faith than hard evidence, 37 a view supported by a 1991 study of performance pay within the health sector that stated '[W]e found no evidence to suggest that improved organizational performance in the private sector is associated with the operation of a formal performance management system. ${ }^{38}$ Later studies have highlighted the difficulties of imposing PRP in appropriate work cultures, particularly in the public service sector, where setting performance measures is difficult for many of the employees. ${ }^{39}$

Lawler highlighted research undertaken in the early 1980s which reported how employees were unable to perceive a direct relationship between pay and performance and also that pay was not the only motivator. ${ }^{40}$ A 2004 review of PRP schemes by Gilman in 16 varied companies in the UK also identified this problem. He found that 'Despite arguments that PRP allows a greater propensity to differentiate between individual performance, all of the schemes were highly centralized in terms of both design and application. Local autonomy was confined to the awarding of ratings, with many managers complaining that their hands were tied by central guidelines. Common factors involved firstly, no genuine link between pay and performance at local levels. The emphasis mainly being on controlling the distribution of pay from the centre. ${ }^{41}$

This inability to identify a direct relationship between pay and performance is often related to poor performance appraisals. In many cases, effective measures of individual performance do not exist and so reward allocation relies on managerial judgements. This subjective process leads to perceptions of unfairness, bias and discrimination. Without proper appraisal mechanisms, PRP systems fail, and often achieve the exact opposite of what their proponents claim for them-namely the creation of resentment, ill-feeling and demotivation of the workforce. As Boyce and colleagues summarized, 'Where there is doubt about the fairness [of awards], performance related pay may be divisive and de-motivating. ${ }^{\prime} 2$

But a more fundamental problem with individual performance appraisals was identified by $\mathrm{W}$ Edwards Deming, who stated that 'performance of the individual 
cannot be measured, except possibly on a long-term basis. ${ }^{23}$ Deming describes how performance is a function of many variables: the employee, the employee's co-workers, the job (or task), the equipment, the materials, the customer, management and supervision, and the working environment. Thus it is the system, not the individual, that has the biggest impact on performance variance, making fair evaluations of employee performance 'inherently impossible' 44

In further criticisms of appraisal problems which are fundamental to the allocation of PRP schemes, Gilman, in a review of such schemes, argued that attempts to determine performance ratings 'were more about identifying the "very best" or the "very worst" performers and not about rewarding performance per se.' 41

In a commentary about pay and reward, Pfeffer reports how William A Mercer, a major American consultancy firm, had concluded that 'most individual merit or performance pay plans share two attributes: they absorb vast amounts of management time and resources, and they make everybody unhappy.' ${ }^{45}$ Rather than scrap all forms of financial incentives, Pfeffer recommends moving towards more group-oriented systems such as profit-sharing and 'gainsharing' — or in other words, focus the reward systems on a team-based approach.

\section{CONCLUSIONS}

It is clear from the evidence we have presented that despite its name change, the Clinical Excellence Awards Scheme differs little in its fundamentals from the Distinction Awards Scheme introduced back in 1948. We have argued that there have been deep and systematic failings in current 'merit pay schemes' in both the private and public sectors. However, a much deeper problem with the current NHS scheme is that it is still attempting to assess and reward individual performance, when the NHS and many private sector workplaces rely on the activities of teams. Lawler, in his review of pay strategies, stated that 'It does not make sense to combine a structure that calls for teams with a reward structure that rewards individual performance excellence.' 46

Recently, research has begun to focus on how to allocate awards or 'merit-pay' on a group- or team-based basis. Some research suggests that team-based pay can be effective in motivating staff. ${ }^{47}$ However, such team-based schemes must also be introduced with sensitivity to avoid the pitfalls of individual PRP schemes and, as Reilly notes, 'In case of relating pay to team performance, you have to have an embedded team structure first. And it may be that it is teamwork and goal setting that has a positive effect rather than the team pay scheme itself.' 48
The impact that team-based incentives can have was illustrated in March 2006, when it was reported that 'employees at the John Lewis Partnership are to receive a $£ 120 \mathrm{~m}$ bonus after the retailer outperformed most of its high street rivals last year. The payout, equivalent to almost eight weeks' pay, will be shared by the group's 64000 employees or "partners"., 49

However, it is clear from other research that many health service workers believe that performance incentives are wrong and, for some, insulting. In their study of PRP schemes, Reilly et al. stated, 'A significant minority of participants believed that it was wrong for them to receive incentives to improve their performance. They did the best they could for their patients and were motivated by the vocation of their work. For some it was even insulting to be offered cash to improve performance, whether the offer was individual or team based. Moreover, those sites that opted for a personal cash bonus did not seem to perform better than those that chose to put their 'winnings' into an improvement fund.' 50

One option for any review of the 'merit pay' schemes would be to consider abolishing them. As Berwick stated in his trenchant editorial The Toxicity of Pay for Performance: 'The best answer I have yet found regarding merit pay for doctors or any group of workers; namely, "Stop it'. Merit pay, "pay for performance" and their close relatives are destructive of what we need most in our health care industry-teamwork, continuous improvement, innovation, learning, pride, joy, mutual respect, and a focus of all our energies on meeting the needs of those who come to us for help.' 51

When asked what the replacement for the Distinction Awards Scheme should be, Peter Bruggen, one of the current scheme's earliest critics, replied 'what's wrong with a basic salary?' 52 Not a view shared by the BMA, which in 1999 stated that 'it would be demotivating if everyone shared the money equally.' 53 However, just for illustration purposes, in 2003 the combined Distinction Awards and Discretionary Awards Schemes cost the NHS nearly $£ 250$ million. If the scheme had been scrapped, each and every consultant would have been entitled to a pay rise of $£ 10000$ per annum.

To meet the needs of the NHS in the 21 st century, it is time to undertake a fundamental review of the 'pay for performance' schemes within the service. Given that most health service personnel work within teams and the demotivating factors associated with individual-based schemes, it does not seem sensible to continue tinkering with a system originally designed in 1948.

Competing interests Professor Esmail is a current award holder and member of the Medical Practitioners Union which campaigns against clinical excellence awards. 


\section{REFERENCES}

1 Rodwin MA. Financial incentives for doctors: Have their place but need to be evaluated and used to promote appropriate goals [Editorial]. BMJ 2004;328:1328-9

2 Davies IT. The National Health Service Consultants' Distinction Award Scheme - history and personal critique. Proc R Coll Physicians Edinb 1998;28:517-34

3 Department of Health. Rewarding Commitment and Excellence in the NHS. Consultation document. Proposals for a new consultant reward scheme. February 2001: 18

4 Smith J, Simpson J. Locally determined performance pay-Better levers exist for improving performance in a health service with disparate values. BMJ 1994;309:495-6

5 NHS Consultants Offer Solution to Pay Dispute. The Independent, 5 February 2003

6 Government Sets Out Proposals For Future Contract For NHS Consultants. 21 February 2001. Available at http:// www.wales.nhs.uk/pressnotices/w01191.htm

7 Available at http://www.doh.gov.uk/nhsclinicalexcellenceawardscheme/ awardscheme.pdf

8 Available at http://195.224.49.93/docs\%5Cpublications\%5C34.pdf

9 Cutler T, Waine B. Incentivizing the poor relation: 'performance' and the pay of public-sector 'senior managers'. Competition \& Change 2005;9:75-87

10 Dowling R, Richardson R. Evaluating performance-related pay for managers in the National Health Service. Int J Human Resource Manag 1997;8:348-66

11 Harrington HJ. Performance improvement: was W. Edwards Deming wrong? TQM Magazine 1998;10:230-7

12 Griffin RP. Why doesn't performance pay work? Health Manpower Management 1992;18:31-3

13 Alimo-Metcalfe B. The poverty of PRP. Health Service Journal 1994;104:22-4

14 Bourne S, Bruggen P. Distinction awards for England and Wales 1977: observations and a look ahead. BMJ 1979;March:638-9

15 Bourne S, Bruggen P. Reviewing the distinction awards system in England and Wales, 1978 and 1979. BMJ 1981;282:1005-7

16 Bruggen P, Bourne S. Further examination of the distinction awards system in England and Wales. BMJ 1976;28:536-7

17 Bruggen P, Bourne S. Third examination of the distinction awards system in England and Wales. BMJ 1977;12:462-3

18 Bruggen P, Bourne S. Secrecy and distinction. BMJ 1987;295:393

19 Bruggen $\mathrm{P}$, Bourne $\mathrm{S}$. The distinction awards system in England and Wales 1980. BMJ 1982;284:1577-80

20 Hansard. 27 January 1998: Column 1997

21 Streetly A. Women consultants and merit awards. BMJ 1994;308:1712

22 Tait A, Platt MJ. Women consultants, their background and training: some myths explored. Med Educ 1995;29:372-6

23 Lester E. Sex distribution of distinction awards. BMJ 1980;280:198

24 Beecham L. Women consultants lag behind in merit awards. BMJ 1994;308:1106

25 See for example the ACDA Annual Report 2001. Available at www.doh.gov.uk/acda/annual.htm

26 Esmail A, Everington S, DoyleH. Racial discrimination in the allocation of distinction awards? Analysis of list of award holders by type of award, specialty and region. BMJ 1998;316:193-5

27 Advisory Committee on Distinction Awards. Annual Report. March 1998:9
28 Warden J. NHS to come under Race Relations Act. BMJ 1998;318:625

29 Department of Health. Rewarding Commitment and Excellence in the NHS Consultation document. Proposals for a new consultant reward scheme, February 2001. Available at www.doh.gov.uk/ nhsclinicalexcellenceawardscheme/

30 Available at www.doh.gov.uk/nhsclinicalexcellenceawardscheme/ awardscheme.pdf

31 Medic Race case settled. No details over Bay Trust agreed terms. Herald Express 11 February 1999:1. Section: Courts, Industrial Tribunal

32 Surgeons settle racism claim. 'Two Asian surgeons yesterday settled a dispute with Plymouth Hospitals NHS Trust after claiming racial discrimination over the allocation of financial merit awards'. Western Morning News 15 January 2000

33 Available at http://www.positive-equality.co.uk/downloads/ section2_case6.doc (accessed 24/01/06)

34 Esmail A, Abel P, Everington S. Discrimination in the discretionary points award scheme: comparison of white with non-white consultants and men with women. BMJ 2003;326:687-8

35 Lambert TW, Goldacre MJ, VallanceE, Mallick N. Characteristics of consultants who hold distinction awards in England and Wales: database analysis with particular reference to sex and ethnicity. BMJ 2004;328:1347-52

36 Kohn A. Why incentive plans cannot work. Harvard Business Review 1993;September/October: 54-63

37 The Economist. 18 January 1992

38 Quoted in Griffin RP. Why doesn't performance pay work? Health Manpower Management 1992;18:31-3

39 Kessler I. Remuneration systems. In Bach S, Sisson K (eds). Personnel Management in Britain: A Comprehensive Guide to Theory and Practice. Oxford: Blackwell Publishers, 2000

40 Lawler DD. Merit pay: fact or fiction? Management Review 1981;April:50-3

41 Gilman GW. The Characteristics of Performance Related Pay Schemes. Working Paper No.59. Canterbury Business School, March 2004

42 Boyce J, Morris T. Performance related pay for hospital doctors-So much for sticks, what about some carrots? BMJ 1992;18:131-2

43 Demming WE. The New Economics for Industry, Government, Education. MIT Center for Advanced Engineering Study, 1994

44 Waite ML, Stites-Doe S. Removing performance appraisal and merit pay in the name of quality. An empirical study of employees' reactions. $J$ Qual Manag 2000;5:187-206

45 Pfeffer J. Six dangerous myths about pay. Harvard Business Review 1998;May/June

46 Lawler EE. Rewarding Excellence. Pay strategies for the New Economy. Jossey-Bass Publishers, 2000:37

47 Gomez-Mejia L, Balkin D. The effectiveness of individual and aggregate compensation strategies in an $\mathrm{R} \& \mathrm{D}$ setting. Industrial Relations 1989;28:431-45

48 Reilly P. New approaches in reward: Their relevance to the public sector. Public Money and Management 2003;October:245-52

49 John Lewis makes $£ 252 \mathrm{~m}$ and gives staff eight weeks' pay bonus. Guardian 10 March 2006

50 Reilly P, Phillipson J, Smith P. Team-based pay in the United Kingdom. Compensation \& Benefits Review 2005;July/August:54-60

51 Berwick DM. The toxicity of pay for performance. Quality Management in Health Care 1995;4:27-33

52 Interview with Peter Bruggen and Sandy Bourne. 10 July 2002

53 McHale M. The merit awards game. Public Finance 1999; September: $16-8$ 